\title{
BLOOD FOR THE GODDESS. SELF-MUTILATION RITUALS AT VAJREŚVART MANDIR, KANGRA ${ }^{-}$
}

\author{
ALEJANDRO JIMÉNEZ CID \\ Universidad Complutense de Madrid \\ dicxela@yahoo.es
}

Received: 01-09-2015

Accepted: 09-01-2016

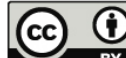

Abstract

Several 17th century sources (European travel literature and Mughal historiography) record the practice of self-mutilation, and possibly ritual suicide, at the Hindu temple of Vajreśvarī (Kāngrāâ, HP), an important place of pilgrimage related to the Śakti cult. Blood-spilling, symbolizing fertility, played a central role in these sacrifices, which were discontinued in the 18 th century as they became discordant with the non-violent representation of Hinduism supported by urban elites.
\end{abstract}

KEYWORDS: blood sacrifice; Hinduism; self-mutilation; goddess; Shakti; Kangra; Himachal Pradesh

RESUMEN Sangre para la diosa: rituales de automutilación en Vajreśvarī Mandir, Kāngrāā

Diversas fuentes literarias del siglo XVII (viajeros europeos e historiógrafos mogoles) registran la práctica de automutilaciones, y posiblemente suicidios rituales, en el templo hindú de Vajreśvarī (Kāngṛā, HP), un importante centro de peregrinación asociado al culto de Śakti. El derramamiento de sangre, símbolo de fertilidad, constituía la parte central de estos sacrificios, los cuales dejaron de realizarse en el siglo XVIII al entrar en conflicto con la visión no violenta del hinduismo promovida por las elites urbanas.

PalabRas ClaVe: sacrificio sangriento; hinduismo; automutilación; diosa; Shakti; Kangra; Himachal Pradesh

\section{The Abode of the Goddesses}

Kāngrāa district, in the past an independent rājpīt state, belongs nowadays to the territory of Himachal Pradesh, ${ }^{1}$ in Northwest India. The modern state of Himachal contains within its borders most of the land that once formed the cluster of petty

\footnotetext{
${ }^{1}$ In this article, I have chosen to transliterate Indian words using ISO 15919 according to modern pronunciation, not Sanskrit pronunciation; i.e., शिव appears as Śiv, not Śiva, or शक्तिपीठ as śaktipițth, not śaktipițha. Certain well-known toponyms, though, are written in their standardized Hunterian transliteration; i.e., हिमाचल प्रदेश appears as Himachal Pradesh, not Himācal Pradeś.
} 
kingdoms that Victorian geographers used to name Panjab Hill States (Hutchinson and Vogel, 1933). Crouching in between the lush Panjābī plains and the desolate TransHimalayan highlands, these states — and Kāngrāa among them — lie in the margins of Indian geography; and let us advance that margins and periphery are concepts which will recur in this article. Indeed, these remote territories have always been conditioned by their geographical location: although not really far, in a straight line, from first-order cultural and political centres such as Delhi or Lahore, historically speaking the contact with them has tended to be somewhat loose due to their inconvenient position in the Śivāliks and the steep Himalayan foothills. This has allowed these rājpūt states to preserve a strong local flavour, as well as their own idiosyncrasy in political, cultural, and religious terms.

In addition to this, Himachal enjoys a widespread reputation as a place of pilgrimage; Hindus call the area dev bhümi, "the abode of the gods" (Sharma, 2007: 11), in line with the ancestral Indian belief of divinities dwelling at the summit of the mountains. Significantly, there are plenty of Mother Goddess cult centres in the area, the most renowned being those of Cāmuṇ̣̂ā near Dharamsala, Nainā Devī in Bilāspur district, Baglāmukhī at Bankhaṇḍ̄in, Cintpūrṇī in Ūnā district, Jvālāmukhī, and Vajreśvarīī $^{2}$ at Kāngrāā (Jerath, 2006: 11-40; Thakur, 1997: 56). Although apparently different goddesses —or goddesses differently named - are worshipped in these sanctuaries, somehow they can all be regarded as manifestations of the same Mother Goddess (Mātā Devi) , or of the same "female principle": Śakti in the jargon of mainstream Hinduism. The concept of Śakti comprehends all the diverse forms of the Goddess, as conflicting as they might seem: Durgā the demon slayer and Pārvatī the perfect wife, the gentle Gaurī and the blood-thirsty Kālī (Thakur, 1997: 55-56).

Some of the most revered shrines of Śakti in the Western Himalayas are related to the myth of Satī, Siv's first wife, who was credited with having immolated herself by the procedure that bears her name - the infamous suttee that outraged both the British colonial authorities and public opinion overseas. As the story goes, Satî’s charred body

\footnotetext{
2 As usually happens with Indian toponyms and theonyms unlinked to literary tradition, there are many alternative spellings for the shrine's name: Bajreśvarī, Brajeśvarī... and, in transliteration, their Hunterian counterparts. We have chosen Vajreśvari as it is more consistent with its Sanskrit etymology, as a compound of vajra ("thunderbolt", and specifically Indra's thunderbolt) and aiśvara ("majesty", or "related to Śiv"). The feminine -ī ending suggests a reading of Vajreśvarī as a name of Śiv’s consort.
} 
was dismembered and scattered all over India: a variant of the Osiriac myth that has proven successful in so many religious systems as the foundation for relic cults. Every spot where a piece of Satī touched the ground became a holy site, a śaktipiṭh ("seat of Śakti"). No less than four parts of the Goddess are said to have landed within the borders of modern Himachal Pradesh (Sharma, 2007: 102): her feet at Cintpūrṇi, her eyes at Naina Devī, her tongue at Jvālāmukhī and her breasts ${ }^{3}$ (or just her left breast; see Jerath, 2006: 26) ${ }^{4}$ at Vajreśvarī. If we trust the classic research of Sir James Frazer, who identified all Osiris-type cults as fertility cults (Frazer, 1922: $362 \mathrm{ff}$.), the place where the Goddess' breasts are worshipped should perforce be a major centre for Śakti cult; and, as we shall presently see, it certainly is.

The geographical setting of Kāngrāa town, capital of its homonymous district and home to the Vajreśvarī shrine, has always been a source of confusion based on the sources alone. Let me clarify this: there are actually two Kāngrāas, some four kilometres away from each other. One is Old Kāngrāa, which is the settlement beneath the fortress of Nagarkot, the former seat of political power; the other is New Kāngrāa, built around the hill where Vajreśvarī temple rises, ${ }^{5}$ surrounded today by a maze of stalls selling religious memorabilia. In the past, travellers used to refer to both Kāngrāās with the name of Nagarkot. The actual Vajreśvarī mandir was completely rebuilt after the 1905 earthquake, which entirely devastated the complex. ${ }^{6}$ It must be noted that Vajreśvarī is often linked —and repeatedly confused — with the nearby śaktipịth Jvālāmukhī, ${ }^{7}$ which lies 40 kilometres south of New Kāngrāā.

Nowadays ritual and devotional activity at Vajreśvarī revolves around a quite standardized Durgā cult, but literary sources reveal that some 300 years ago things were different, and the hilltop shrine at Kāngrāa was renowned as the scene for a most unusual type of sacrifice. For this very reason, despite being located off the main commercial

\footnotetext{
${ }^{3}$ Sometimes it is hard to realize that the part of Satī worshipped in Kāngrāa is actually her bust, due to the many euphemisms used both by Indian and Western authors: "the upper part of her body", "the body"... (Vigne, 1842: 140)

${ }^{4}$ Jerath's main informant during his research at Vajreśvarī was the main priest of the temple, Rām Prasad.

${ }^{5}$ Sources written centuries ago call this sacred hill Malekra or Bhavān (Vigne, 1842: 140), although these names are unknown to our local informants.

${ }^{6}$ The building, which was destroyed in the earthquake, dated from 1440, according to the Imperial Gazetteer of India (vol. 14, p. 386). After 1905, the Ārya Samaj helped with massive donations to the rebuilding of the shrine.

${ }^{7} J v \bar{a} \bar{a} \bar{a} m u k h \bar{\imath}$ ("fiery countenance", or "fiery mouth") is the official name, but is not widely used; the locals usually call it $J v \bar{a} \bar{a} \bar{\jmath} \bar{l}$.
} 
routes of the Mughal Empire, we have many accounts of 17th century travellers and geographers, both Muslim and Western, who were attracted to Kāngrāa, eager to witness the prodigy that was supposed to take place at the Goddess' temple. It roughly consisted of a ritual where devotees put themselves into an ordeal involving self-mutilation (or even self-immolation!) and miraculous healing (or even resurrection!). To know more about it, we must turn to our primary sources, where we find once and again the elements that constitute the grammar of this particular cult — but the different versions do not completely accord, so a reconstruction of actual facts is more than difficult.

\section{The Accounts}

Probably the first notice about Vajreśvarī that can be traced in Western sources appears in Samuel Purchas' compilation of travel accounts, published in 1614 as Purchas his Pilgrimage. It refers to an earlier source (but there is no way to know how much earlier), the work of an obscure author called by Purchas Ioannes Oranus. His description of the ongoing practices at Kāngrāa goes as follows:

Not farre from the Citie Lahor [Lahore] is an Idoll, resembling a woman, which they call Nazar Coto [Nagarkot], framed with two heads, and six or seven armes, and twelve or fourteene hands, one of which brandisheth a Speare, another a Club. Hereunto resort many Pilgrims to worship, and hereof they tell many miracles; as that many cut off their tongues, which are againe restored whole vnto them, but remaine mute. (Purchas, 1614: 478)

In 1611, the English merchant William Finch wrote a more detailed account clearly biased by his own moral judgement on the basis of Protestant ethics:

[...] In which city [Nagarkot, or Negercoat in Finch's spelling] is a famous pagod called Je [Jai] or Durga, unto which worlds of people resort out of all parts of India. It is a small short idoll of stone, cut in forme of a man; much is consumed in offerings to him, in which some also are reported to cut off a piece of their tongue and, throwing it at the idols feet, have found it whole the next day (able to lye, I am afraid; to serve the father of lyes and lyers, how ever); yea, some out of impious piety heere sacrifice themselves, cutting their throats and presently recovering. The holyer the man, the sooner forsooth he is healed; some (more grievous sinners) remaining halfe a day in paine before the divell will attend their cure. Hither they resort to crave children, to enquire of money hidden by their parents or lost by themselves; which, having made their offerings, by dreames in the night receive answere, not one departing discontented. They report this pagan deity to have beene a woman (if a holy virgin may have that name); yea, that shee still lives (the divell shee doth) but will not shew her selfe. Divers Moores also resort to this peer [Pers. pir , a saint]. (Foster, 1921: 179-180) 
It is worth noting that, according to Finch's report, not only Hindus but also Muslims ("divers Moores”) were attracted to the rituals at Vajreśvarī — and let us point out that Muslim onlookers would have been travelling from afar, considering that, even during the golden age of the Mughals, this part of India remained almost untouched by the Islamification process. It was obviously the alleged miracle itself, and not the elements of Hindu religiosity, that struck non-Hindus and Hindus alike. Most famous is the case of Emperor Akbar himself, who heard about Vajreśvarī and wanted to attend the ceremonies personally. Nevertheless, when he was on his way, Akbar was prevented from doing so by a prophetic dream, as recorded by historian Abu'l-Fazl in his Akbarnāme (written 1590-96):

\begin{abstract}
One of the occurrences was that H.M. [Akbar] turned his thoughts towards Nagarkot. When he heard of the wonders of that ancient place of pilgrimage, and especially of the restoration there of tongues that had been cut off, his truth-seeking heart was attracted towards that place. At this time, when he was near that spot, the wondrous tale again occurred to him, and on the 15th (Farwardin) he went thither with a few special intimates to see the marvel. [...] The difficulties of the way and the rugged defiles had somewhat fatigued the companions of dominion, but from awe of the Divine majesty — which is a powerful closer of the tongue - no one ventured to say anything. During that night a spiritual form - which had wondrous powers - appeared in the secret place of dreams. It recited the lofty rank of the world's lord and restrained him from his intention. In the morning he mentioned the vision and returned. A great delight took possession of every one. (Beveridge, 1939: vol. 3, 348)
\end{abstract}

After William Finch, the next Western account mentioning the wonder is Edward Terry's (1590-1660); based on the text of his A Voyage to East India (first published 1655, although his travels date back to the decade of 1610), ${ }^{8}$ it is unclear if Terry visited Kāngrāa himself or if he just put into writing things described by the famous adventurer Thomas Coryat (1577-1617), whom he quotes as eye-witness:

Nagracot [Nagarkot], the chief city so called, in which there is a Chapel most richly set forth, being ceiled and paved with plate of pure silver, most curiously imbossed over head in several figures, which they keep exceeding bright, by often rubbing and burnishing it; and all this cost those poor seduced Indians are at, to do honour to an idol they keep in that chapel [...]. The idol thus kept in that so richly adorned chapel, they called Matta [Mātā Devī], and it is continually visited by those poor blinded Infidels, who, out of the oficiousness of their devotion, cut off some part of their tongues to offer unto it as sacrifice; which (they say) grow out again as before: But in this I shall leave my reader to a belief, as much suspensive as is my

\footnotetext{
${ }^{8}$ Hutchinson and Vogel (1986: 8) date Terry's visit in 1615.
} 
own in this particular. [...] These places were seen and strictly observed by Mr. Coryate. (Terry, 1777: 82-83)

The testimony of French traveller Jean de Thévenot $(1633-1667)^{9}$ keeps in line with the one quoted above; in its early English translation (1687) it reads like this:

There are two Pagods of great reputation in Ayoud, the one at Nagarcut [Nagarkot], and the other at Calamac [Jvālāmukhī]; but that of Nagarcut is far more famous than the other, because of the Idol Matta [Mātā Devī], to which it is Dedicated; and they say that there are some Gentiles, that come not out of that Pagod without Sacrificing part of their Body. (Thévenot, 1687: vol. 3, 62)

Travel literature and ethnographical research written in the early 19th century (Hugel, 1845; Moorcroft and Trebeck, 1841; Vigne, 1842) cease to mention the selfmutilation ritual that constantly recurs, as shown above, in 17th-century sources. This absence is significant, as authors such as William Moorcroft spent long periods of time in Kāngrạa and recorded minutely historical and ethnographical facts about the region. So we can conclude from this evidence that whatever bloody ritual was performed in the Vajreśvarī shrine was discontinued around the mid-18th century.

Turning now to the descriptions of the ritual according to the aforementioned sources, we find in them a group of common elements along with some contradictions. We can summarize what we know by postulating that the 17th-century literary sources provide evidence of an ongoing sacred activity at Vajreśvarī which featured certain acts of self-mutilation as part of the cult of a certain goddess. But the different records do not match regarding two crucial questions: a) what kind of mutilation? b) which goddess? Let us try to find some answers.

\section{Mother of Tongues}

Some of the quotes above illustrate how, "out of the oficiousness of their devotion", some individuals would cut out their own tongue, or a significant part of it, as an offering to the Goddess. And, what is more, the accounts of Ioannes Oranus, Abu'l-Fazl, Finch and Terry record that, according to local belief, the severed tongues of devotees would grow back in an extraordinarily short period of time; Terry is the only one among them that, reasonably enough, expresses scepticism on this miraculous

\footnotetext{
${ }^{9}$ Hutchinson and Vogel (1986: 9) consider uncertain whether Thévenot ever visited Nagarkot.
} 
healing. It must be realized that, in William Finch's 17th-century mindset, such a feat might have been possible due to the supernatural powers of the "divell", and we must concede that, out of fanaticism, it is perfectly plausible that the devotees were actually gashing and even cutting out their tongues; but no matter how strong their faith was, it is clinically impossible to have a severed tongue regrown overnight. Should we think, then, that the self-sacrificers were performing a fake mutilation, a display of visual trickery akin to the famous Indian rope trick, which likewise featured explicit mutilations and a happy end ${ }^{10}$ The answer is no. It is not possible because the rope trick, gruesome and gory as it may seem, was in essence an act of entertainment, while self-mutilation rituals in Kāngrạa were religious practices performed within a sacred space. Sacrality implies the observance of a protocol that, although not necessarily excluding trickery and deceit, would not accept deceptive effects that can be looked upon as gimmicks for their own sake, as those staged by prestidigitators or illusionists in a secular performance. Nevertheless, ritual substitution, as a symbolic device of make-believe, could have been perfectly admissible in a religious context: that is to say, mimicking the act of cutting one's own tongue ${ }^{11}$ —and perhaps gashing it so that blood spurts out - and offering the divinity a substitute accepted by tradition, i.e. an animal's tongue or any other token.

It is possible as well that the report of full tongues being severed is simply an exaggeration of some practices that involved self-mortification -including tongue gashing and piercing - just as we find nowadays in South India, related to the cult of Kālī (Obeyesekere, 1981: 158), or in the well-known Thaipusam festival celebrated by Hindu communities of Southeast Asia and on the islands of Mauritius and Réunion. Field research made by Colleen Ward (1984) on self-torturing participants of Thaipusam has shed some light on psychic and physiological processes experienced by

${ }^{10}$ In its classic form, the rope trick was performed by a sorcerer and his assistant, a boy. First the magician hurled a rope end up to the sky, so the rope remained up straight, hanging from an invisible point in the dark (so we have to assume that the trick was practiced by night). Then the sorcerer had his assistant climb the rope, so he disappeared too. When the boy failed to come back at his master's calling, the angry sorcerer would climb the rope himself with a knife. The bewildered spectators watched how the boy's limbs fell to the ground one by one, his head last. Then the magician descended, with bloodsplattered clothes, and at the request of the audience he put back together the boy's limbs and restored him to life. (Eliade, 1960: 682-684)

${ }^{11}$ As witnessed by anthropologist David Pocock in a Kālī ritual in Gujarat:

The most dramatic appearance was reserved for the end when the bhuvo snatched up a rusty and blunt old sword from the shrine and, pressing its edge on to his tongue with both hands sucked vigorously at the blood which was supposed to be flowing. (cit. in Obeyesekere, 1981: 154) 
people undergoing such an ordeal, and to a certain extent it can help us to understand and reconstruct the practices performed at Vajreśvarī some three hundred years ago. Dr. Ward concludes that someone who puts himself into an altered state of consciousness -by means of what Mircea Eliade, in his classic work about shamanism, called "techniques of ecstasy" - can actually endure large amounts of pain; also, an individual can minimize bleeding, or even withhold it completely, in mortification practices that may include piercing the tongue with skewers and hooks. ${ }^{12}$ But, as I shall point out later in this article, it is not likely that bloodshed was to be avoided: on the contrary, blood, as a fecundatory principle, constituted the very essence of the sacrifice.

But why should tongue-cutting be part of a Goddess cult? To begin with, an act of self-mutilation seems perfectly fit, by analogy, for worship at a śaktipițh: a shrine built in memory of a divine being that was torn apart, as the myth goes. Besides, we must remember that one of the most prominent features of the Goddess in her fierce aspect (i.e. Kālī) is her lolling red tongue. ${ }^{13}$ But let us pose a third speculation: according to Molu Rām Thakur (1997: 63), the Goddess at Kāngrāa is also worshipped under the advocation of Devī Bakbani, goddess of eloquence. It goes without saying that the organ of eloquence par excellence is the tongue. So, following a bhakti-tinted devotional logic, sacrificing one's own tongue to the divinity would be the best way to improve eloquence, as exemplified by a folk legend about the poet and playwright Kālidās, the literary father of Śakuntalā:

Kalidasa was a simpleton whose wife could not tolerate him. Determined to win her affection he invoked Kali by offering her his own head (or tongue) as sacrifice. The goddess was so pleased that she restored Kalidasa to life. She then swallowed him and vomited him out. By entering the body of the goddess, Kalidasa was cleansed of all stupidity. He emerged as a talented poet. No sooner was he reborn from the mouth of Kali than he began composing a hymn in praise of the goddess. (Mohanty, 2004: 58)

The whole story was probably born as a pun on the poet's name: most suitably, Sanskrit $K \bar{a} l \bar{l}+d \bar{a} s a$ means "servant of Kālī"; but the ritual element of voluntarily

\footnotetext{
12 "Most devotees appear to control both pain and bleeding, aided by the sharpness of the hooks and the administration of holy ash to the points of insertion, as well as by the trance state itself." (Ward, 1984: 321)

${ }^{13}$ This is the explanation given by a practitioner of self-mutilation rituals in South India to anthropologist Gananath Obeyesekere: "But why the tongue, I persisted? 'Because Mother Kali's own tongue protrudes, and so she placed the knife on my tongue [during possession trance]." (Obeyesekere, 1981: 158)
} 
offering a part of oneself to the Goddess is there: one's tongue, or head, as we shall presently see.

\section{Ritual Self-Beheading: Off With My Head!}

Bhakti, traditionally associated with folk Hinduism, puts a stress on blind faith as the most meritorious quality of a devotee; and certainly an exceedingly large amount of faith is needed in order to believe that someone can have his head chopped off and live to tell the tale. But self-beheading, and a subsequent restoration to life, happens to be a recurrent topic in the mythic contents of śakti cults, particularly in connection with the fiercest manifestations of the Goddess (Kālī, Cāmuṇụā, and the like). In an image that blurs the oppositions between victim, sacrificer, and oblation-receiving divinity, the goddess Chinnamastā is typically pictured right after her act of self-beheading, holding her own freshly severed head, her tongue sticking out to drink the blood that squirts out of her neck. (Kooij, 1999: 249 ff.; Kinsley, 1987: 172 ff.)

Besides William Finch's account, already quoted in this article, there is a folk legend worth mentioning in relation to the mandir at Vajreśvarī: that of the holy man Dhyānu Bhagat, contemporary to Akbar, who allegedly cut off his own head as a sacrifice to Durgā; some say this happened at Vajreśvarī, others at its sister shrine Jvālāmukhī (Doniger, 2009: 561), both of them being important seats of Durgā worship. At the Vajreśvarī complex, there is a slab of stone - smeared with a thick orange layer of turmeric, vermillion and ghee paste - depicting Dhyānu Bhagat's ghastly offering (Jerath, 2006: 27). The story became so popular that they made it into a film, a devotional movie directed and protagonized by Panjābī film star/singer/wrestler Dārā Singh $^{14}$. The film reaches its climax when a standing Dhyānu Bhagat stretches out his arms, holding his freshly cut head in his hands and presenting it to the cult image of Durgā at the shrine; at once, the Goddess materializes as a smiling young lady wrapped in a shiny spangled sari and restores Dhyānu's life and physical integrity. ${ }^{15}$

\footnotetext{
${ }^{14}$ Dhyānu Bhagat (1978); originally in Panjābī, it was dubbed in Hindī in 1979 and released under the title Bhakti mẽ Śakti.

${ }^{15}$ There are many different variants of Dhyānu Bhagat's story. Aśok Jerath records a version in which Dhyānu, "a staunch disciple of the goddess", put himself into a trance, severed his own head and offered it to Durgā no less than six times; but then "the goddess warned his disciple in dream that she would not bless him for the seventh time". Nevertheless, Dhyānu beheaded himself one last time and died in a state of bliss. So this version actually ends in ritual suicide. (Jerath, 2006: 27)
} 
At the end, the tale of Dhyānu Bhagat provides an etiological myth for sacrificial substitution in the Durgā $p \bar{u} j \bar{a}$, as narrated in a recent devotional pamphlet:

If he [Dhyānu Bhagat] wished any other item, he should tell her [the Goddess]. Dhyanu fell at her feet. [...] He only wished that the devotees need not be put to such a severe test. He had offered his head. But all could not do that. He requested that ordinary gifts of the devotees, should be taken as her offerings. She agreed to that and told that in future only a coconut would be accepted, as an offering. (Chaturvedi, 2001: 47)

Dry coconuts are, in fact, customary $p \bar{u} j \bar{a}$ offerings in present-day pan-Indian Durgā cult, but we must keep in mind, as Dhyānu Bhagat's story exemplifies, that they are substitutes of human heads that were offered to the Goddess back in the past (Doniger, 2009: 561). Further evidence for this substitutional operation can be found today in the nearby śaktipițha complex of Jvālāmukhī, where an act of mock beheading is performed as the central part of a darśan ritual ${ }^{16}$ of goddess Durgā. Pilgrims wait in line and walk through an initiatory circuit inside the sanctuary (including a narrow passage between two massive rocks, the Mother Goddess' thighs: a ritual performance of rebirth) before eventually reaching the mürti, the cult image itself. One by one, pilgrims ceremonially bow their heads and an assistant hits them gently with a cane on the back of their necks. So, at least symbolically, heads still keep rolling at the Goddess' feet in Kāngrāa district. ${ }^{17}$

\section{Reconstructing the Ritual}

Leaving the details aside, we can therefore agree that what used to happen in Vajreśvarī and seized the attention of Europeans and Mughals alike was some sort of visually shocking self-mutilation ritual dedicated to a local Mother Goddess - the literal translation of $M \bar{a} t \bar{a} \operatorname{Dev} \bar{\imath}$, as Terry and Thévenot explicitly call her. Modern

16 In Hinduism, the rite of darśan (Sanskrit darśana, "gaze") is a two-directional means of communication (divinity-devotee) based on eye contact between the pilgrim and the cult image (mürti). It is said to be bidirectional because the devotee sees the divinity and, at the same time, the divinity sees the devotee.

17 This was not an isolated phenomenon; as specialist David Kinsley wrote, "Iconography and literature contain many examples of people who sacrifice their own blood and pieces of their flesh to goddesses; ritual suicide, usually self-decapitation, is also well documented as an act of devotion to goddesses. [...]In Kșemendra's Bṛhatkathāmañjarī a washerman and his brother-in-law cut off their heads in a fit of devotional fervour to the goddess Gaurī. In an inscription dated A. D. 991 from the Kannada area we hear of a loyal subject named Katega who offered his head to the goddess Gundidadabe to fulfill a vow when the king succeeded in fathering a son. Four similar scenes from Pallava and early Chola sculpture depict kneeling male devotees offering their heads to a four-armed goddess." (Kinsley, 1987: 145) 
Hinduism, in its tendency towards monism, has been working on strengthening the bonds between the manifold folk goddesses, considering them all as manifestations of one and the same Śakti. But we have to keep in mind that this is a modern construction, so the unique nature of the cult and identity of every local Mother Goddess is not to be neglected. Today the brāhman priests at the temple prefer to call her Vajreśvarī Devī (just "The Goddess of Vajreśvar $\overrightarrow{1}$ ”), in order not to raise any doubt regarding her individuality (Sharma, 2007: 103).

Something remains to be said about the nature of the cult image that received the sacrifice. In this respect, the 17th-century sources previously quoted must not be followed to the letter, as they are strongly biased: outsider views on Indian cults and beliefs were projected on their versions of whatever happened at Vajreśvarī. For that reason, most of them insist on the fact that the ceremonies were performed in front of an anthropomorphic statue of the Goddess ("cut in forme of a man") —an "idoll", or a $m \bar{u} r t i$, to use the Hindu term for it. Both Christians and Muslims typically used to regard Hindu belief as a religion of idolaters, therefore tending to project their preconceptions on to their descriptions of the ritual. In an early display of Orientalistic prejudice, what they expected to find there was an impressive, many-limbed, anthropomorphic idol ("framed with two heads, and six or seven armes, and twelve or fourteene hands") receiving its gory tributes: a stereotype fitting to the blood-thirsty Moloch of the Old Testament. But, although there are - and certainly there were - several striking, and artful, images of many-limbed goddesses lining the courtyard walls of Vajreśvarī, none of them is the cult image that, according to the believers, endows the shrine with a unique sacredness. The real cult object does not resemble a woman at all: it is a pind $\bar{l}$, a shapeless lump of rock covered in orange paste on which a pair of eyes have been roughly painted (Jerath, 2006: 23). Local tradition says that it is Satī's left breast, torn off by Viṣnu and petrified as it touched the ground. This is undoubtedly the object onto which the most relevant rituals converge at the shrine, nowadays as well as three hundred years ago and probably longer before: Persian historian Ferishta (1560-1620) records that this object, which he calls Sheokot Pindi, was already worshipped near Nagarkot prior to the time of Mohammed (Briggs, 1829: lxxviii). It is, then, most probable that Western visitors to Kāngrāā were more impressed by the colourful sculptures - made by man, not by God - scattered all about the temple complex than 
by the uncomely and modest pind $\bar{l}$ lying in the inner sanctum, failing to realize that the petrified breast — made by God, not by man — was the real cult image.

By comparison with other similar practices still running today in peripheric Hindu communities (e.g. those performed at the Thaipusam festival in Malaysia), it is possible to reconstruct the process of the ritual to some extent. It has to be emphasized that what follows is based on my own conjectures, on the grounds of a comparative study of ritual forms, without any textual basis to support it. However, taking into consideration the available data, I regard the presence of analogy between the extinct practices at Vajreśvarī and present-day Thaipusam as a valuable working hypothesis. Thus, the participants would prepare themselves for the sacrifice through a previous period of fasting and penance that would help them achieve the state of consciousness necessary for the act of self-mutilation. As it was a practice wherein, as I have discussed, the spilling of blood was mandatory, being associated with the fertility myth of the dismemberment of Satī and with the worship of the Goddess' breasts, all selfsacrificing participants must have been male. ${ }^{18}$ Women's blood is related to menstrual blood, hence considered as an impure substance either in folk or high-brow Hinduism, with the exception, of course, of left-hand Tantra rituals, provocatively focused on "forbidden" fluids. So the very essence of the ritual was blood, and it was smeared on sacred objects. The ubiquitous vermillion, turmeric and ghee paste that covers cult images nowadays is an obvious substitute for the layer of clotted blood that once dripped down their surface. ${ }^{19}$

However, besides the display of sheer faith, devotion, and self-control, did the participants expect any personal benefit from the ritual? As Colleen Ward summarizes:

Hindus have historically placed great value on ecstatic trance and development of supernatural powers through austerity. In addition, there has been a traditional predisposition to compel the gods to fulfill requests through extreme practices of self-discipline and self-mortification. (Ward, 1984: 326)

\footnotetext{
${ }^{18}$ In his study of the rituals prescribed by the Tärä-tantram, A. K. Maitra writes: "The offering of blood from the body of the devotee is held to be an offering of real efficacy as distinguished from the offering of blood of animals. [...] But female devotees have been distinctly forbidden to offer blood" (Maitra, 1913: 20). The interdiction of female participation in blood-related rituals of the Goddess is a fact neglected by the wave of new age Western feminists that claim Durgā and the śakti goddesses as role models for an empowered and free modern woman. (Amazzone, 2012)

${ }^{19}$ As observed by Diana L. Eck. (cit. in Kinsley, 1987: 240)
} 
Finch recorded some of the requests that Vajreśvarī devotees used to make: wealth and offspring, obviously the latter being the typical boon a goddess of fertility is expected to grant. These are the same type of petitions requested from the divinity by many participants in the self-torture practices of Thaipusam in Malaysia; others put themselves into the ordeal in fulfillment of a vow (Ward, 1984: 318).

Scholars have hypothesized that Mother Goddess cults in the Indian subcontinent have a pre-Indoeuropean origin; in the Vedic tradition female deities play minor roles. The inclusion of Śakti goddesses as major members of the Hindu pantheon seems to be a later development of the brahminical religion, the result of a process of syncretism of Indo-Aryan texts and local beliefs. That is why the places where Mother Goddess cults have remained more powerful are usually to be found in peripheral contexts, far from the centers of "official" brahminical culture and religion: either in the social periphery - lower castes ${ }^{20}$ — or in the geographical periphery — South India, Bengal, the mountain regions, Southeast Asia. As I have pointed out before, the hill state of Kāngrạa lies at the margins of the Indian world; due to this, it became a perfect milieu for the preservation of an ancient system of rituals and beliefs centered in a local Goddess. It remains for us to evaluate the causes that led to the discontinuity of selfmutilation rituals in Vajreśvarī.

\section{Sanitizing the Cult}

Over the last two hundred years, Hinduism has experienced a major transformation. On the one hand, local beliefs all over India have become more centralized and subject to attempts of systematization, difficult though it may be, taking into account the overwhelming heterogeneity of cults within the subcontinent. On the other hand, from the early 19th century on, "Renaissance" Hindus ${ }^{21}$ — adherents to the reform movements such as Ārya Samāj, Brāhmo Samāj, Vedānta Society and Hindu urban elites in general - have been most reluctant to allow a continuity of those aspects of folk Hinduism that clashed with their cosmopolitan, Western-friendly conception of the Hindu creed. The foremost of these uncomfortable aspects was the violence

20 Like the Kālī-worshipping Śabaras, a tribe of primitive hunters, as described in Bāṇabhațta's Kādambarī and Vākpati's Gaudavaho. (Kinsley, 1987: 117)

${ }^{21}$ I use the term coined by Austrian anthropologist Aghenanda Bharati: "Renaissance Hinduism [is] associated with modern, urbanized, reformed, and to a certain extent Westernized spirituality associated with such teachers as Ramakrishna and Vivekananda." (Newell, 2011: 33) 
embedded in many traditional religious practices, namely self-torture and animal sacrifice (Caldwell, 2003: 262). Activities such as these stand in straightforward contradiction with the "harmlessness" principle of ahimsāa: during the struggle for independence, Hinduism wanted to publicize itself in a globalizing world by projecting an image of pacifism and nonviolence. Cleansing folk Hinduism of its "R-rated" sides is a slow process that still goes on nowadays. Animal sacrifice has been officially banned in Himachal Pradesh as recently as $2014,{ }^{22}$ and controversy still rages on over this decision of the High Court.

Self-mutilation practices, like those once observed at Vajreśvarī, stand in a more ambiguous relation to the ahims $\bar{a}$ principle, as they deal with self-inflicted violence, which is basically a manner of self-mortification; and self-mortification is deeply linked to asceticism, so dear to Hindu religious life. The apparently pointless violence suffering for its own sake- of self-mutilation and self-immolation practices in India have been haunting the Western imaginary since the early descriptions by European travellers of ritual suicide in Orissa, where devotees threw themselves under the wheels of the cart of Jagannāth: ${ }^{23}$ a word that got standardized in English as juggernaut, standing for a ruthless advancing force that crushes everything in its path. Ruthless and diabolical: such is precisely the colonial image of Hindu gods and goddesses as divinities rejoicing in destruction, widow-burning and bloody rituals - a stereotype perpetuated in 20th century popular culture through films like Gunga Din (directed by George Stevens, 1939) and Indiana Jones and the Temple of Doom (directed by Steven Spielberg, 1984) (Kotwal, 2005; Caldwell, 2003: 250-251). The colonial sensationalist construction of a blood-stained Hinduism of thugees and juggernauts is exactly what Indian urban elites wanted to exorcize, sanitizing every element of folk rituals and beliefs that could misleadingly point in that direction.

\footnotetext{
22 "Indian court bans animal sacrifice", The Guardian (UK), 2 September 2014.

${ }^{23}$ Its most famous description is that of Mandeville's Travels:

And they set this idol upon a car with great reverence [...] and they lead him about the city with great solemnity. [...] And some of them [the pilgrims] fall down under the wheels of the car, and let the car go over them, so that they be dead anon. And some have their arms or their limbs all to-broken, and some the sides. And all this do they for love of their god, in great devotion. And them thinketh that the more pain, and the more tribulation that they suffer for love of their god, the more joy they shall have in another world. (Mandeville, c.1375: 117).
} 
Further proof of this is the fact that in Malaysia, a Muslim country where Hindu communities stay preeminently in a rural background and the influence of Hindu urban elites on them is not as strong as in India, bloody self-mortification rituals have remained at the core of certain festivals, like Thaipusam (Ward, 1984: 317). There, after undergoing an initiation and entering into a trance, devotees pierce their bodies with hooks and skewers and endure various forms of penance and self-torture. The Indian advocates of an aseptic sanätan dharm have tried their best to avoid any linkage of such type of rituals, clearly akin to those happening in Vajreśvarī around the year 1600, to their own view of a politically correct Hinduism, suitable for all audiences.

Some scholars have proposed that this transformation of Hindu religion was triggered by its encounter with Protestant morals and British public opinion, so "sanitized" modern Hinduism would be a by-product of colonialism (Pennington, 2005). But, despite the undeniable influence of Western exposure in the development of Hinduism over the last two hundred years, our case exemplifies that the cleansing process that aimed to supress bloody rituals in peripheral cults is an inside conflict which started much before the colonial era. My diachronic study of literary sources concerning ritual activity at the Vajreśvarī mandir (see above) has shown that it was widely reported during the first half of the 17th century, but we can infer from the analysis of later documents that self-mutilation rites had been permanently discontinued somewhere in the 18th century. Lacking textual evidence about any activity in the temple for a period spanning more than a hundred years, we are struck by a complete disappearance of descriptions of the ritual in Kāngrāa-related travel literature dating from late 18th century onwards. Detailed and valuable eye-witness accounts like those of George Forster (published in 1798), William Moorcroft (1841), Godfrey Vigne (1842) or Charles von Hügel (1845) do not say a single word concerning such a noticeable issue; a significant omission, which offers a stern contrast with its status as a wellknown local attraction in the aforementioned 17th century sources. The sudden cessation of centuries-old rituals within a relatively short period of around a hundred years strikes us as puzzling, and forces us to reconsider the generalizations that we have just discussed about the reasons that made this type of acts of devotion sink into oblivion. The fact is that, prior to the arrival of the reform movements of the 19th century, the local cult at Kāngrāa had already suppressed its most controversial features. 
Such a development, pointing towards a sanitized Hinduism much before this became the official trend, can be explained by two rival hypotheses: a) the changes came from outside, which means that the conflict between local cults (featuring violent practices from time immemorial) and urban elites (supporting ahims $\bar{a}$ and the textual tradition) already existed long before the foundation of Ārya Samaj and the like; b) the suppression of violent elements in Vajreśvarī could perfectly be part of an internal line of development, regardless of external influences or pressures. Neither of these explanations is wholly satisfactory. Our best chance to understand the decline and fall of the blood rituals at Vajreśvarī lies in a combination of both viewpoints. Keeping this in mind, further research on the subject would be needed in order to shed some light on the circumstances and particular reasons behind it.

As we have seen, the strategy for reducing ritual violence has focused on a policy of substitutions: ${ }^{24}$ coconuts for heads, vermillion paste for blood, and so on. This way, ritual violence apparently disappears; but, as physical laws say about matter, violence can be considered an energy that cannot be destroyed, but just displaced —or transformed. René Girard theorized that the violent elements in religion are an institutionalized resource needed by human groups in order to get rid of their aggressive instincts, which otherwise would still need to be discharged somewhere else (Girard, 1972: 12 ff.). Thus, the violence of sacrifice is a way of harnessing and controlling the outbursts of violence that are inherent to the human species. It is tempting to think that Girard was not wrong at all when we think of modern Hinduism: bloody ceremonies like those at Vajreśvarī - have been sanitized in the name of ahims $\bar{a}$, while at the same time religious violence has increased dramatically, as shown in the ongoing tensions between Hindus and Muslims in contemporary India.

\footnotetext{
${ }^{24}$ About patterns of substitution in Hindu ritual, see Das, 2013: 19-20.
} 


\section{WORKS CITED}

Amazzone, Laura (2012). Goddess Durgā and Sacred Female Power, Plymouth: Hamilton.

BEVEridge, Henry (1939). The Akbarnama of Abu'l-Fazl, Calcutta: Asiatic Society of Bengal.

Briggs, John (1829). History of the Rise of the Mahomedan Power in India, Till the Year A. D. 1612. Translated from the Original Persian of Mahomed Kasim Ferishta, vol. 1, London: Longman.

Caldwell, Sarah (2003). "Margins at the Center. Tracing Kālī through Time, Space, and Culture", In: Rachel Fell McDermott \& Jeffrey J. Kripal (eds). Encountering Kälì. In the Margins, at the Center, in the West, Berkeley: University of California Press: 249-272.

Chaturvedi, B. K. (2001). Vaishno Devi, Delhi: Diamond.

DAS, VeEnA (2013). "Violence and Nonviolence at the Heart of Hindu Ethics", In: Mark Juergensmeyer, Margo Kitts \& Michael Jerryson (eds). The Oxford Handbook of Religion and Violence, Oxford: Oxford University Press: 15-40. DOI: 10.1093/oxfordhb/9780199759996.001.0001

Doniger, Wendy (2009). The Hindus. An Alternative History, London: Penguin.

Eliade, MirceA (1960). "Le 'miracle de la corde' et la préhistoire du spectacle", La Nouvelle Revue Française, Vol. 8: 682-693.

Foster, WiLliam (1921). Early Travels in India 1583-1619, Oxford: Oxford University Press.

Frazer, James (1922). The Golden Bough. A Study in Magic and Religion, Chatham: Wordsworth, 1993.

GIRARD, RENÉ (1972). La violence et le sacré, Paris: Grasset. (Spanish translation: La violencia y lo sagrado, Barcelona: Anagrama, 1998)

Hügel, Charles von (1845). Travels in Kashmir and the Panjab, London: John Petheram.

Hutchinson, John \& Vogel, Jean-Philippe (1933). History of the Panjab Hill States, Lahore: Asian Educational Services.

Hutchinson, John \& Vogel, JeAn-PhiLipPe (1986). History of Kangra and Kullu States, Delhi: Northern Book Centre. 
JERATH, ASHOK (2006). Shrines of Shakti in the Western Himalayas, Jammu: Association of Litterateurs, Folklorists and Artists.

KInSLEY, DAVID (1987). Hindu Goddesses. Vision of the Divine Feminine in the Hindu Religious Tradition, Delhi: Motilal Banarsidass.

KOOIJ, KAREL R. VAN (1999). "Iconography of the battlefield: the case of Chinnamastā", In: Jan E. M. Houben \& Karel R. van Kooij (eds). Violence Denied. Violence, Non-Violence and the Rationalization of Violence in South Asian Cultural History, Leiden: Brill: 249-274.

Kotwal, KaIZAAD NAVROZE (2005). "Steven Spielberg's Indiana Jones and the Temple of Doom as Virtual Reality: The Orientalist and Colonial Legacies of Gunga Din", Film Journal, Vol. 1, No 12, April 2005 [without pagination].

Maitra, Akshaya Kumara (1913). Tārā-tantram, Calcutta: Pandit Purandara Kāvyatirtha.

MandeVILLE, John (c.1375). The Travels of Sir John Mandeville, London: Macmillan, 1915.

Meyer, William Stevenson; Burn, Richard; Cotton, James Sutherland \& RISLEY, HERBERT HOPE (1908). Imperial Gazetteer of India, vol. XIV: Jaisalmer to Karā, Oxford: Clarendon Press.

Mohanty, SeEma (2004). The Book of Kali, Noida: Penguin.

Moorcroft, William \& Trebeck, George (1841). Travels in the Himalayan Provinces of Hindustan and the Panjab, in Ladakh and Kashmir; in Peshawar, Kabul, Kunduz, and Bokhara, vol. 1, London: John Murray / Asiatic Society of Calcutta.

Newell, Zo Margaret (2011). Picturing the Goddess: Bazaar Images and the Imagination of Modern Hindu Religious Identity (doctoral dissertation), Nashville: Vanderbilt University.

ObeyeseKere, Gananath (1981). Medusa's Hair. An Essay on Personal Symbols and Religious Experience, Chicago: University of Chicago Press.

Pennington, Brian K. (2005). Was Hinduism Invented? Britons, Indians, and the Colonial Construction of Religion, Oxford: Oxford University Press. DOI: 10.1093/0195166558.001.0001

Purchas, SAmuel (1614). Purchas his Pilgrimage, or Relations of the World and the Religions Observed in All Ages and Places Discovered, from the Creation unto This Present, London: William Stansby.

Sharma, B. R. (2007). Gods of Himachal Pradesh, Delhi: Indus Publishing Company / Institute of Integrated Himalayan Studies. 
TERRY, EDWARD (1777). A Voyage to East-India, London: J. Wilkie.

Thakur, Molu Ram (1997). Myths, Rituals and Beliefs in Himachal Pradesh, Delhi: Indus Publishing Company.

THÉVENOT, JEAN (1687). The Travels of Monsieur de Thevenot into the Levant, London: H. Clark.

Vigne, Godfrey (1842). Travels in Kashmir, Ladak, Iskardo, the Countries Adjoining the Mountain-course of the Indus, and the Himalaya, North of the Panjab, vol. 1, London: Henry Colburn.

WARD, COLLEEN (1984). "Thaipusam in Malaysia: A Psycho-Anthropological Analysis of Ritual Trance, Ceremonial Possession and Self-Mortification Practices", Ethos, Vol. 12, № 4: 307-334.

AlejandRo JimÉnEz CID is a $\mathrm{PhD}$ Student in the Departament of Ancient History, Faculty of Geography and History at the Complutense University of Madrid. 